\title{
The Determinants of Risk-Sharing Strategies of Food-Retailers: A Study on Chittagong, Bangladesh
}

\author{
Awlad Hosen Sagar ${ }^{1}$, Md Abu Bakkar Siddik ${ }^{2} \&$ Rubayet Hasan ${ }^{2}$ \\ ${ }^{1}$ Department of Finance, University of Chittagong, Bangladesh \\ 2 Department of Banking and Insurance, University of Chittagong, Bangladesh \\ Correspondence: Awlad Hosen Sagar, Department of Finance, University of Chittagong, Bangladesh. E-mail: \\ sagar.fb@cu.ac.bd
}

Received: September 15, 2020

Accepted: November 11, 2020

Online Published: December 22, 2020

doi:10.5430/ijfr.v11n6p337

URL: https://doi.org/10.5430/ijfr.v11n6p337

\begin{abstract}
Food-retailers have access to various risk management strategies to manage the risks in food processing and trading. Risk-sharing is a powerful instrument amongst risk management strategies. It comprises a negotiation of risk allocation between at least two agents to reduce risk and to increase expected utility. The objective of the study is to identify the factors that affect the selection of risk-sharing strategies of food-retailers. In this regard, the study explains risk-sharing instruments from three perspectives: risk reduction; risk mitigation; and risk coping strategies. Food-retailers choose these risk-sharing strategies according to their preference. We link a theoretical understanding of the existing risk-sharing strategies with an empirical model. For quantitative analysis, primary data encompassing 24 variables is sampled from 109 randomly selected food-retailers from and around the city of Chittagong, Bangladesh. This study uses a multiple regression model to identify the significant factors in selecting risk-sharing strategies. The results infer that Family Employment, Hired Employment, Value Chain Challenges, Institutional Challenges, Societal Challenges, Risk Attitudes on Marketing and Promotion, Risk Attitudes on Innovation, Risk Attitudes on Business-in-General, Gender and Expectation for Succession, have a significant effect on the selection of risk-sharing strategies. The analysis is performed on SPSS (version-26). This study covers only off-business risk-sharing instruments of food-retailing. Consequently, this result is irrespective of on-business risk management strategies.
\end{abstract}

Keywords: risk reduction, risk mitigation, risk coping, off-business risk sharing strategies

\section{Introduction}

To manage the risks in food processing and trading, food-retailers have access to various risk management strategies. For example, strategies include; risk-sharing, risk avoidance, risk reduction, and risk acceptance. The main aim of all strategies is to minimise losses and to ensure desired profitability. Risk-sharing comprises a contract where risk is shared between actors representing a negotiation of risk allocation between at least two agents where they employ state-contingent risk reduction and increase expected utility. Risk-sharing is a win-win situation where economic stability is increased by all parties involved. The food-retailing environment is dynamic and stakeholders are encouraged to seek private solutions for managing their risks. As a private solution risk-sharing is perceived as advantageous for both individuals and society (Meuwissen et al., 2001). Common risk-sharing strategies are insurance, future and option contracts, subcontracting, hedging, value chain collaboration, shared-equity arrangements, and group production agreements. Informal quasi-credit is also a risk-sharing strategy employed the developing world counties which solves enforcement problems and ensures income pooling arrangement between actors (Marcle, 1999). Eventually, it maximises the value of the company. However, the frequency and impact of risk are the main determinants in selecting an appropriate risk management strategy. In this regard, a risk-sharing strategy is used whenever the frequency of risk is low but the impact of risk is large. It can be employed at any stage in business; for example, risk-sharing in production, pricing, and financing. Whatever the moment of risk-sharing, the main basis is the pooling and spreading of risk across other stakeholders. Food-retailers use many risk-sharing strategies during the transition of production and trading. Whenever risks influence production, equity capital, and net income of the business risk-sharing is needed as a part of business planning and risk management. Sometimes, food-retailers arrange a portfolio of risk-sharing strategies over the whole business period, for example, one risk-sharing strategy (e.g. 
insurance) might be used for production risk while simultaneously another risk-sharing strategy (e.g. hedging) might be used for marketing and pricing risk.

\section{State-of-the-Art}

Risk is an inherent characteristic of any business. Food-retailing is more prone to risk due to high volatility in pricing and uncertainty in demand. Chavas, (2004) focused mainly on three reasons behind this risk and uncertainty: a) inability to control and/or measure causal factors of events; $b$ ) limited ability to process information; $c$ ) monetary cost of a decision. To manage various risks, food-retailers usually uses on-firm and off-firm risk management instruments. The most common risk management tool is insurance. It appears to be a better solution compared to risk reduction benefits. There are various types of insurances. To some extent, investors use property insurance to reduce risk while simultaneously a hedging/private arrangement allows reducing price risk. The off-business income, education, forward contract in sales, and networking positively affects the use of hedging (Mishra \& El - Osta, 2002). For financial security small food-retailers in developing countries also rely on a reciprocal financial exchange, kinship ties, and community self-help by joining informal risk-hedging schemes, becoming members of a micro-finance institution, and cooperatives based on reciprocal social relationships (Cox \& Fafchamps, 2006). Therefore, the penetration of insurance remains small in developing countries due to the unwillingness of actors (Mahul \& Stutley, 2010). Moreover, a risk-averse business does not use contracts and risk-seeking actors do not use contracts all the time. Evidence suggests that Chinese firms use contracts not only to mitigate price risk but to also reduce marketing and transaction costs (Holly, Zhang \& Wu, 2011), and religious castes also matter in India (Munshi \& Rosenzweig, 2006). Apart from demography, Murgai et al. (2002) focus on the transaction cost in using local risk-sharing strategies. Velandia et al. (2009) explained the adoption of insurance, forward contracting, and spread sales as risk-sharing strategies. They identified the proportion of business ownership, off-business income, education, age, and level of business risks that significantly affect the adoption of risk management tools. Besides, the size of a business is associated with price risk, while the legal side of business is associated with production risk and income risk (Nadezda, Dusan \& Stefania, 2017). Shiferaw, Okello \& Reddy, (2007) focus on market linkages, access to finance, and the availability of pro-poor options for beneficial conservation. Furthermore, technological innovation in market structure and public policy intervention also affect risk management strategies (Feder \& Umali, 1993). Improved technological innovation reduces the downside risk by protecting production (Emerick et al., 2016). Then again, risk attitudes offer insight into why two food-retailers may behave differently given an identical situation. One may prefer to explore the opportunity while another may not. All these factors potentially influence the intended decision of risk-sharing strategies of food-retailers in Chittagong, Bangladesh.

\section{Problem Statement}

Recently, the market for food-retailing in Bangladesh is growing fast due to the increasingly prominent love of dining-out. 50\% of the total population of Bangladesh is under 25 years old, mostly preferring to eat out as a matter of socialisation. Food-retailing is also deemed to be quite profitable. It is one of the dominant avenues for creating employment as entrepreneurs and employees in Bangladesh. It is estimated that food-retailing contributes to $2.1 \%$ towards the country's GDP. There is also a tradition in Chittagong; of eating rich-food and feeding others. As such there are many food-retailers in Chittagong, Bangladesh, but each is prone to risk and uncertainty. To manage risk and uncertainty they use on-business and off-business (risk-sharing) strategies. There is plenty of literature on specific risk-sharing instruments. For instance, insurance is the most common risk-sharing strategy (Harwood et al., 1999), and which ensures income, though it has maladaptive outcomes due to non-adjustment and production (Pocuca, Petrovic \& Mrksic, 2018). Insurance is also a careful instrument for managing risks from a local, social, economic, and ecological perspective (Muller, Johnson \& Kreuer, 2017). However, food-retailers don't rely only on insurance as a whole risk management solution. They arrange a set of risk management instruments including risk-sharing tools. However, there is limited literature regarding the factors affecting the risk-sharing strategies of food-retailers. Meraner et al., (2015) studied the determinants of diversification. Therefore, the corresponding research gap is to what extent thefollowing selected factors matter in deciding risk-sharing strategies and use of riks sharing instrumens among food-retailers, the individual characteristics of food-retailers, business characteristics, risk perceptions, and risk attitudes. Furthermore, risk-sharing strategies are associated with the willingness to take a risks by food-retailers. Some food-retailers may also determine to take more risks during production, marketing, and pricing, financing, and innovation stages, or generally in their overall business as opposed to and in comparison to other retailers. By considering all these factors, this study will assess the determinants of risk-sharing strategies. To what extent these four domains of factors (i.e., personal characteristics, business characteristics, risk perception, and risk attitudes) play a role in the selection of risk-sharing strategies will be assessed by this study. As such, the main objective of the study is to identify the factors affecting risk-sharing strategies of food-retailers of Chittagong, Bangladesh. 


\section{Conceptual Model}

The theoretical framework addresses how food-retailers' characteristics, subjective risk perceptions, risk attitudes, and business characteristics matter in selecting risk-sharing strategies. It involves the selection of methods for countering all risks to meet a risk-averting goal. To get insight into risk-sharing, all possible risk-sharing strategies are clustered into three forms: risk reduction; risk mitigation, and risk coping.

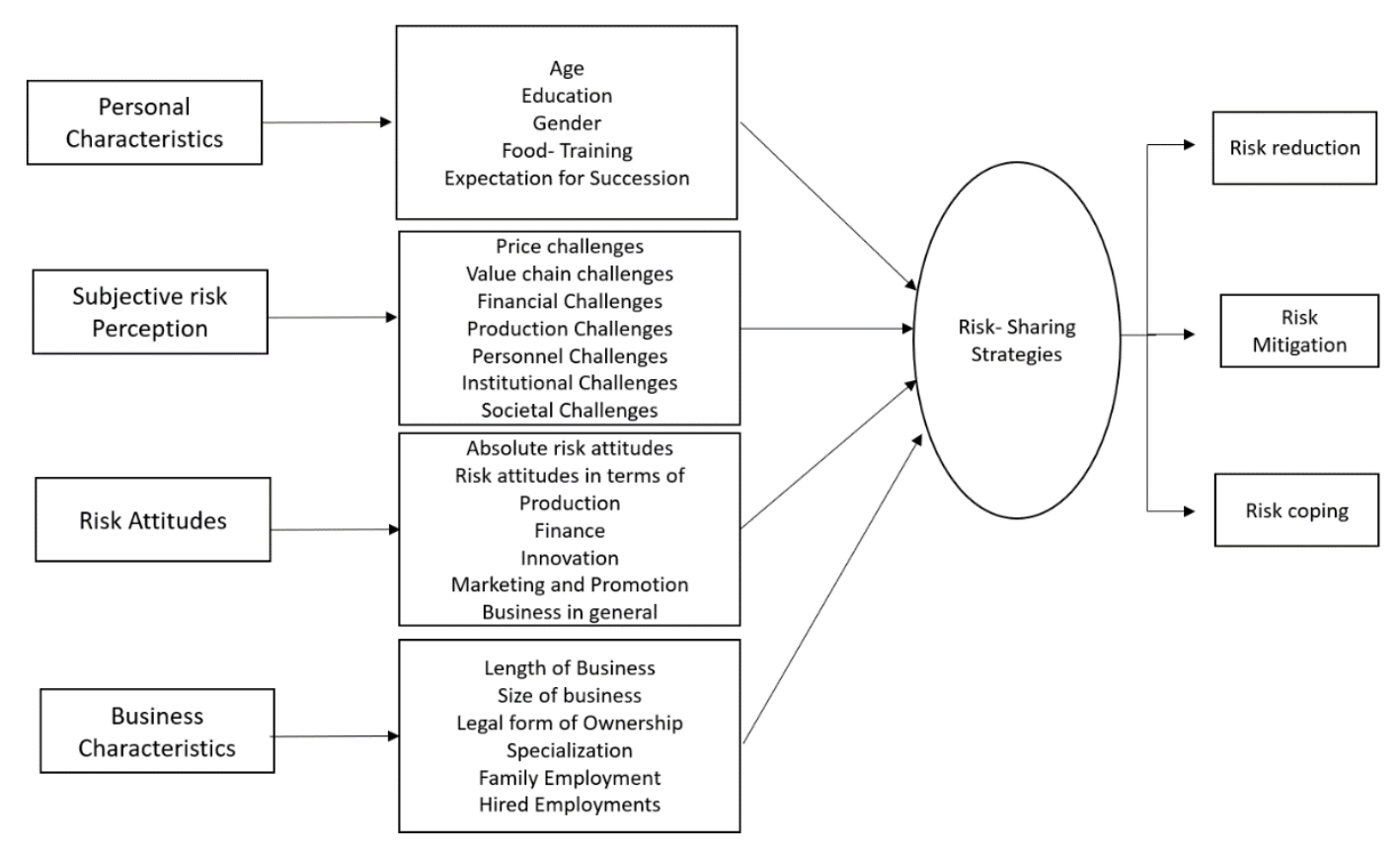

Figure 1. Theoretical framework of risk-sharing strategies

\subsection{Assumptions of the Model}

This study presumes that food-retailers use various risk-sharing strategies considering their associated risks in procurement, processing, or trading. This study assessed whether four factors (i.e. personal characteristics; subjective risk perception; risk attitudes and relative risk attitudes; and business characteristics) do matter in the selection of risk-sharing strategies. The dependent variables are risk-sharing strategies. This study has adequate independent variables that are continuous, ordinal, or nominal, and observations are independent. There is no multi-collinearity amongst the selected independent variables. There is a linear relationship between continuous independent variables. Finally, there are no outliers, high leverage values, or highly influential points.

\subsection{Food-Retailer's Characteristics}

This study checks whether food-retailers personal characteristics have a direct (not mediated) effect on the risk-sharing strategies. For instance, age (Finocchio \& Esposti, 2008), gender (Larson et al., 2015), succession (Meraner \& Finger, 2019), experience (Saqib et al., 2016) and education (Velandia et al., 2009) all affect risk management. These characteristics significantly affect the adoption of risk management tools. However, all these studies explained the effect of personal characteristics on a single risk management tool (e.g. uptake of contracts, credit and insurance) or overall risk management. No studies have yet been conducted on the effects that these personal characteristics of food-retailers have on the choice of risk-sharing strategies in Bangladesh. Hence, this study proposes the following hypothesis based on the above-mentioned literature:

\section{H1: Personal characteristics explain the choice of risk-sharing strategies}

\subsection{Subjective Risk Perception}

Risk perception of actors might be different due to the subjective judgment of food-retailers towards the objective risk. For example, one food-retailer may be more concerned with price risk and another may be more concerned with 
production risk; one retailer might insure for production risk whereas another chooses to hedge (private arrangement) or draft a future contract for price risk. Additionally, price risk, production risk and income risk (Nadezda, Dusan \& Stefania, 2017; Meuwissen, Huirne \& Hardaker, 2001), and weather-based risk perception (Ullah, Shivakoti \& Ali, 2015) influence risk management strategies. Therefore, based on the above literature this study expects that food-retailers with a hedge perceived risk are more likely, to adopt risk-sharing strategies. Hence it is hypothesised that:

\section{H2: Food-retailer's risk perception positively influences on the choice of risk-sharing strategies.}

\subsection{Risk Attitudes and Relative Risk Attitudes}

Risk attitude has been described in economics literature by expected utility frameworks (Pennings \& Garcia, 2001). The study measures risk attitudes of food-retailers in two forms: a) absolute risk attitude, and; b) relative risk attitudes. It measures absolute risk attitudes as the willingness to take a risk. Relative risk attitudes are measured as the willingness to take more risks compared to others in terms of production, marketing, and price, finance, innovation, and business-in-general. Though risk attitude is typically regarded as stable over time, it changes under different temporal and contextual conditions (Dohmen et al. 2011). A decision-maker may be simultaneously be risk loving and risk-averse under different conditions (Hansson \& Lagerkvist, 2012; Pennings \& Smidts, 2000; Starks \& Trinidad, 2007). For example, an investor may show risk-loving attitudes in production but may be risk-averse in financing and innovation. As such this study expects that the more willing food-retailers are to take risks, the less motivated they are to adopt risk-sharing strategies. Hence, this study proposes the following hypothesis.

H3: Risk aversion and relative risk aversion (to other food-retailers) have a negative impact on the choice of risk-sharing strategies.

\subsection{Business' Characteristics}

This study has separated the business from an individual by its characteristics; business size (Lucas \& Pabuayon, 2011), specialisation (Benni, Finger \& Mann, 2012), ownership proportion (Saqib et al., 2016), and the roles of family employees (Benjamin \& Kimhi, 2006), and how these affect risk management strategies. This study will assess whether these have a direct effect on the risk-sharing strategies of food-retailers. This study will also also assess whether the perceived experience has a significant effect on risk-sharing strategies. Based on the above literature the following hypothesis is proposed:

\section{H4: Business characteristics have a significant impact on the choice of risk-sharing strategies.}

To test the above hypotheses, the variables along with their notation are presented in the following table (Table 1).

Table 1. List of explanatory variables of this study

\begin{tabular}{lllc}
\hline \multicolumn{1}{c}{ Variables } & \multicolumn{1}{c}{ Notation } & \multicolumn{1}{c}{ Variables } & Notation \\
\hline Age & & Risk Attitudes & \\
Gender & $\mathrm{Ag}_{\mathrm{fp}}$ & Risk attitude in General & $\mathrm{RA}$ \\
Expectation for succession & $\mathrm{Gr}_{\mathrm{fp}}$ & Relative risk attitudes in production & $\mathrm{Pn}_{\mathrm{rra}}$ \\
Education & $\mathrm{Suc}_{\mathrm{fp}}$ & Marketing and prices & $\mathrm{Mp}_{\mathrm{rra}}$ \\
Food-retailing Education or training & $\mathrm{Edu}_{\mathrm{fp}}$ & Financial risks & $\mathrm{Fn}_{\mathrm{rra}}$ \\
Subjective Risk Perception & $\mathrm{F}_{\mathrm{Red}}$ & Innovation & $\mathrm{In}_{\mathrm{rra}}$ \\
Price challenges & & Business Characteristics & \\
Value chain challenges & $\mathrm{Pr}_{\mathrm{rp}}$ & Business in general & $\mathrm{Fg}_{\mathrm{rra}}$ \\
Financial challenges & $\mathrm{VC}_{\mathrm{rp}}$ & Length of business & $\mathrm{Ln}_{\mathrm{fc}}$ \\
Production challenges & $\mathrm{Fr}_{\mathrm{rp}}$ & Food specialization & $\mathrm{As}_{\mathrm{fc}}$ \\
Personal and personnel challenges & $\mathrm{Pn}_{\mathrm{rp}}$ & Legal form of business & $\mathrm{Lf}_{\mathrm{fc}}$ \\
Institutional challenges & $\mathrm{PP}_{\mathrm{rp}}$ & Size of business & $\mathrm{Ts}_{\mathrm{fc}}$ \\
Social challenges & $\mathrm{Ins}_{\mathrm{rp}}$ & Family Employment & $\mathrm{FEf}_{\mathrm{fc}}$ \\
\hline
\end{tabular}




\subsection{Explanation of Dependent Variables}

Food-retailers report that they have access to multiple risk-sharing instruments. We thus assume that they are using these risk-sharing instruments to manage risks. The choice of risk-sharing strategies available to a food-retailer are not mutually exclusive since they would be accessing risk-sharing instruments from more than one source instrument in their risk management portfolio. During the survey, they report eight different risk-sharing instruments. These eight instruments are clustered together in three categories based on risk management literature. Categories of the risk-sharing instrument and their example are stated in the following table (Table 2).

Table 2. Categories of risk-sharing instruments based on risk management literature

\begin{tabular}{|c|c|c|}
\hline Sl. No. & Category & Types of risk-sharing instrument \\
\hline 1 & Risk reduction $\left(\mathrm{R}_{\mathrm{r}}\right)$ & $\begin{array}{l}\text { Risk reduction covers measures decreasing the probability of an } \\
\text { adverse event affecting the business. For example, cooperation with } \\
\text { other food-retailers to secure inputs of production (e.g. buying inputs } \\
\text { together, sharing machinery or exchanging production), having access } \\
\text { to a variety of input suppliers and learning about challenges in } \\
\text { food-retailing (e.g. food-retailers groups, consultations, or training). }\end{array}$ \\
\hline 2 & Risk mitigation $\left(\mathrm{R}_{\mathrm{m}}\right)$ & $\begin{array}{l}\text { Risk mitigation indicates the strategies that allow the risk to happen, } \\
\text { but reduce its impact (Wauters et al., 2014). Like risk reduction, it is } \\
\text { also employed before the risk occurs. Mitigation strategies reduce the } \\
\text { potential impact of the risk if it were to occur (Holzmann \& Jørgensen, } \\
\text { 2001). For example, membership of an (inter)branch organisation, } \\
\text { collaboration with value chain actors such as technology providers, } \\
\text { buying any types of insurance; (e.g. property insurance, yield } \\
\text { insurance). }\end{array}$ \\
\hline 3 & Risk coping $\left(\mathrm{R}_{\mathrm{c}}\right)$ & $\begin{array}{l}\text { Risk coping is related to restoring the whole or part of the property } \\
\text { damaged and when. It is essentially the residual strategy if all else has } \\
\text { failed. For example using production or marketing contracts to sell (a } \\
\text { part of) production and hedge (a part of) production with futures } \\
\text { contracts. }\end{array}$ \\
\hline
\end{tabular}

\section{Data Operationalisation}

This study comprises primary data. The respondents are food-retailers in Chittagong, Bangladesh. Data has been collected through a structured questionnaire. The questionnaire consists of open-ended and closed-ended questions that gather information on the characteristics of food-retailers, risk perceptions, risk attitudes, and risk-sharing instruments. The total number of respondents is 120 food-retailers in Chittagong, Bangladesh. The data was collected from November - December 2019.

\subsection{Data Management, Cleaning, and Organisation}

The data set consists of 24 variables observed over 120 food-retailers. The variables cover the demographic aspects of food-retailers, the businesses themselves, risk-related variables, and functional aspects. These 24 variables have been selected as explanatory variables for the research design based on the literature and research gap. Moreover, these 24 variables have been grouped into four broad domains. The dataset is formed through survey questionnaires using a random sampling method. There are a variety of respondents regarding the size of the business, types of business, ownership, and their specialisation. We reframe this raw dataset according to our research objectives. We also derive a few variables from collected data through literature and simple calculation.

\subsubsection{Data Cleaning, Outlier, and Strange Observations}

The variables of risk perceptions and risk attitudes are measured in terms of a seven-point Likert scale. The variables of personal characteristics and business characteristics are measured in simple numerical values. To identify any strange data, we detect outliers with the help of the following statistical formula graphical identification through boxplots of the respective variables. 


$$
\begin{aligned}
I Q(\text { Inter Quartile }) & =3^{\text {rd }} Q-1^{\text {st }} Q \\
\text { Upper fence } & =\left\{3^{\text {rd }} Q+(1.5 * I Q)\right\}
\end{aligned}
$$

Therefore any value greater than the "Upper fence" is considered an outlier for this variable. Moreover, there may be a 'typo error' or the respondents may not have understoo the question of the interviewer. For example, a food-retailer may respond that the total number of family labor is 750 units which may not be possible. Meanwhile, we detect all the outliers of all explained variables. We filter the dataset based on the outliers for the respective variables. Besides, there are many variables (e.g., age) in this study which are very subjective for the respondents, their surroundings, and related to the business area. Finally, we get 109 observations (i.e., $90 \%$ of the main dataset) for analysis.

\subsection{Descriptive Statistics of Factors}

The explanatory variables that potentially influence food retailers' risk-sharing strategies are defined as age, gender, education level, succession, and others. The descriptive statistics of their characteristics, business characteristics, and other independent variables of the survey questionnaire is presented in the following table (Table 3 ).

Table 3. Descriptive statistics of food-retailer's and business' characteristics

\begin{tabular}{lcccc}
\hline Variables & Mean & St. Deviation & Maximum & Minimum \\
\hline Length of business & 7 & 6.16 & 26 & 1 \\
Age & 35.89 & 6.98 & 50 & 20 \\
Size of Business & 1747.63 & 1834.82 & 7000 & 120 \\
Family Employment & 0.50 & 0.80 & 2 & 0 \\
Hired Employment & 18.06 & 19.59 & 110 & 5 \\
\hline
\end{tabular}

Table 4. Frequency distribution of the selected explanatory variables

\begin{tabular}{lcc}
\hline Variables & Frequency & Percentage \\
\hline Male & Gender & 90.8 \\
Female & 99 & 9.2 \\
Total & 10 & 100 \\
\hline & 109 & \\
\hline No Education & Education & 0 \\
Primary Education & 0 & 4.6 \\
Secondary Education & 5 & 19.2 \\
Undergraduate Education & 21 & 31.2 \\
Graduate Education & 34 & 45 \\
Total & 49 & 100 \\
\hline & 109 & 6.4 \\
\hline Training & 7 & 93.6 \\
No training & 102 & 100 \\
Total & 109 & 34.9 \\
\hline & Food Education and Training & 34.9 \\
\hline Local food and traditional food & 38 & 02.7 \\
Fast food and continental & 38 & 2.8 \\
Non-meat and sea fish food & 0 & 22 \\
Meat based food & 3 & \\
Mixed activities & 24 & \\
& & \\
\hline
\end{tabular}


Other

6

109
5.5

100

\begin{tabular}{lcc}
\hline & Expectation for Succession & \\
\hline No expectation & 9 & 8.3 \\
Take-over to family & 84 & 77.1 \\
Sell property & 10 & 9.2 \\
Give up tenancy & 3 & 2.8 \\
Others & 3 & 2.8 \\
Total & 109 & 100 \\
\hline & Legal form of the business \\
\hline Sole proprietorship & 52 & 47.7 \\
Partnership business & 57 & 52.3 \\
Company orgainzation & 0 & 0 \\
Co-operative organization & 0 & 0 \\
Total & 109 & 100 \\
\hline
\end{tabular}

\subsection{Multi-Collinearity Test and Empirical Model}

Before conducting the final multiple regression model using the selected twenty-four variables, we check the correlation coefficient of all these variables. A condition index was used to detect correlation (Belsley, Kuh \& Welsch, 1980). We could not find any strong positive or negative co-relation amongst the explanatory variables. The correlation coefficient matrix of explanatory variables is maximum, $r=0.61$. Moreover, we also identify the Variation Inflation Factor (VIF) for each explanatory variable. Contrary to the suggestion of Menapace, Colson \& Raffaelli (2013) and van Winsen et al. (2014). We presume that if the value of VIF > 10 then we assume, that there is multi-collinearity among the explanatory variables. In this dataset, all the values of VIF are lower than 6.58. The proposed methodology derives insight on the food-retailers personal characteristics, risk perception, risk attitudes, and business characteristics that lead to the selection of risk-sharing strategies. Empirically the model may be specified as follows;

Where, $i=$ food-retailers' $i d, Y_{i 1}=1$, use $\left\{\begin{array}{c}Y_{i 1}=X^{\prime}{ }_{i 1} \beta 1+\varepsilon_{i 1} \\ \text { risk sharing strategy. } X_{i}^{\prime}\end{array}\right\}$

$=$ vector of the factors affecting uses of risk-sharing strategies, $\beta_{\mathrm{j}}=$ vector of unknown parameters, and $\varepsilon=$ the error term. The hypotheses can be tested by running independent multiple regression models. The unknown parameters are to be estimated and $\varepsilon_{\mathrm{ij}}$ is the unobserved error term. We assuming the error terms across risk-sharing strategies of a food-retailers are normally distributed with a mean vector equal to zero. We estimate the model using SPSS (version 26).

\section{Results}

Table 5 reports the estimated marginal effects on the probabilities of each variable. For continuous independent variables, marginal effect measures the change of probability given a one-unit change of the independent variable, holding all other variables constant. Grossly, ten factors out of 24 variables show a significant result in the model; Family Employment, Hired Employment, Value Chain Challenges, Institutional Challenges, Societal Challenges, Risk Attitudes on Marketing and Promotion, Risk Attitudes on Innovation, Risk Attitudes on Business-in- General, and Gender, Expectation for succession all significantly, affect the selection of risk-sharing strategies. 
Table 5. Result of the estimated model for risk-sharing strategies

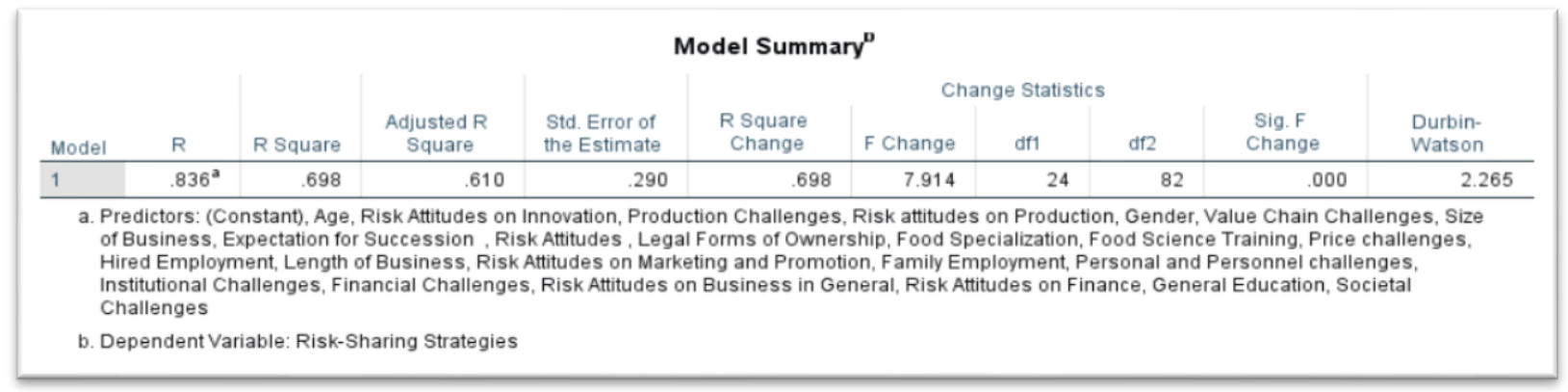

It is evident that- $61 \%$ (i.e., adjusted r-square $=.610$ ) of the risk-sharing strategies of food-retailers are explained by the these ten significant variables if other constant. The Durbin-Watson ratio is 2.26 (i.e., the rule of thumb for Durbin-Watson ratio is 1.5-2.5). Moreover the detailed co-efficient of each of the variables is shown in the following table (Table 6).

Table 6. The individual co-efficient and multicolinearity outcome of all explained variables

\begin{tabular}{|c|c|c|c|c|c|c|c|c|c|c|}
\hline \multicolumn{11}{|c|}{ Coefficients $^{a}$} \\
\hline \multirow[b]{2}{*}{ Mode } & & \multicolumn{2}{|c|}{ Unstandardized Coefficients } & \multirow{2}{*}{$\begin{array}{c}\text { Standardized } \\
\text { Coefficients } \\
\text { Beta }\end{array}$} & \multirow[b]{2}{*}{$\mathrm{t}$} & \multirow[b]{2}{*}{ Sig. } & \multicolumn{2}{|c|}{$95,0 \%$ Confidence Interval for $B$} & \multicolumn{2}{|c|}{ Collinearity Statistics } \\
\hline & & $\mathrm{B}$ & Std. Error & & & & Lower Bound & Upper Bound & Tolerance & VF \\
\hline \multirow[t]{25}{*}{1} & (Constant) & 2.130 & 1.084 & & 1.964 & .053 & -.027 & 4.287 & & \\
\hline & Length of Business & .011 & .008 & .142 & 1.421 & .159 & -.004 & .026 & .367 & 2.724 \\
\hline & Food Specialization & .053 & .036 & .201 & 1.494 & .139 & -.018 & .124 & .204 & 4.913 \\
\hline & $\begin{array}{l}\text { Legal Forms of } \\
\text { Ownership }\end{array}$ & -.023 & .082 & -.025 & -.278 & .782 & -.187 & .141 & .463 & 2.160 \\
\hline & Size of Business & $-2.579 \mathrm{E}-5$ & .000 & -.102 & -1.243 & .217 & .000 & .000 & .546 & 1.830 \\
\hline & Family Employment & -.239 & .070 & -.416 & -3.436 & .001 & -.378 & -.101 & .251 & 3.979 \\
\hline & Hired Employment & .020 & .003 & -.840 & -6.118 & .000 & -.026 & -.013 & .195 & 5.130 \\
\hline & Price challenges & .085 & .055 & .208 & 1.556 & .124 & -.024 & .194 & .206 & 4.846 \\
\hline & Value Chain Challenges & .106 & .026 & .372 & 4.073 & .000 & .054 & .158 & .440 & 2.272 \\
\hline & Financial Challenges & -.002 & .030 & -.010 & -.082 & .935 & -.062 & .057 & .260 & 3.852 \\
\hline & Production Challenges & .004 & .021 & .018 & .209 & .835 & -.038 & .047 & .473 & 2.114 \\
\hline & $\begin{array}{l}\text { Personal and Personnel } \\
\text { challenges }\end{array}$ & -.052 & .035 & -.206 & -1.476 & .144 & -.123 & .018 & .189 & 5.285 \\
\hline & Institutional Challenges & .210 & .034 & .802 & 6.262 & .000 & .143 & .277 & .224 & 4.461 \\
\hline & Societal Challenges & -.141 & .032 & -.674 & -4.333 & .000 & -.205 & -.076 & .152 & 6.577 \\
\hline & Risk Attitudes & -.005 & .029 & -.014 & -.172 & .863 & -.064 & .054 & .589 & 1.698 \\
\hline & $\begin{array}{l}\text { Risk attitudes on } \\
\text { Production }\end{array}$ & .078 & .062 & .185 & 1.261 & .211 & -.045 & .201 & .171 & 5.840 \\
\hline & $\begin{array}{l}\text { Risk Attitudes on } \\
\text { Marketing and Promotion }\end{array}$ & -.197 & .059 & -.416 & -3.347 & .001 & -.314 & .080 & .238 & 4.199 \\
\hline & Risk Attitudes on Finance & .055 & .040 & .182 & 1.376 & .173 & -.024 & .134 & .211 & 4.738 \\
\hline & $\begin{array}{l}\text { Risk Attitudes on } \\
\text { Innovation }\end{array}$ & .129 & .033 & .423 & 3.850 & .000 & .062 & .195 & .304 & 3.285 \\
\hline & $\begin{array}{l}\text { Risk Attitudes on } \\
\text { Business in General }\end{array}$ & -.268 & .046 & -.695 & -5.812 & .000 & -.360 & -.176 & .257 & 3.889 \\
\hline & Gender & -.657 & .147 & -.414 & -4.473 & .000 & -.949 & -.365 & .429 & 2.332 \\
\hline & $\begin{array}{l}\text { Expectation for } \\
\text { Succession }\end{array}$ & -.134 & .064 & -.209 & -2.102 & .039 & -.261 & -.007 & .372 & 2.692 \\
\hline & General Education & .057 & .073 & .110 & .770 & .444 & -.090 & .203 & .179 & 5.589 \\
\hline & Food Science Training & -.247 & .184 & -.132 & -1.341 & .184 & -.613 & .119 & .379 & 2.639 \\
\hline & Age & .000 & .009 & -.005 & -.038 & .970 & -.017 & .017 & .219 & 4.566 \\
\hline
\end{tabular}


Firstly, Expectation for Succession and Gender as personal characteristics have significant negative effects on the selection of risk sharing strategies. For example, under; 'Expectation for Succession', the -0.134 for risk-sharing strategies' suggests that for one unit change in 'Expectation for Succession' score, the coefficient of multiple regression for risk-sharing will decrease by that amount. In other words, if expectation for succession increases one unit, the chance of using risk- sharing strategies decreases by 0.134 units, but Meraner \& Finger (2019) explain anticipation for succession as being more likely to focus on on-business risk management tools and investing in diversification ventures. Moreover, Pottrer \& Lobley (1996) also explain that anticipation for succession focuses on setting up capital to provide a living for the next generation. Secondly,the result of business characteristics shows that employment has a negative effect on risk sharing strategies this finding is somehow the reverse of other studies; For example, Benni, Finger \& Mann; (2012), and Meraner \& Finger; (2019) find a positive and significant effect on on-business and off-business risk management. Meraner, et al., (2015) report that the availability of family labor has a significant negative influence on only on-business risk mangement. The findings of this study also do no't align with the findings of Mishra et al. (2004). The divergence of this result might be due to higher variability of employment in food-retailing. These new findings may be due to high variation in the dataset of hired labor (i.e., mean $=18.6$ and standard deviation = 19.59). Similarly, the legal form of business also matters in the selection of risk sharing instruments (Saquib et al., 2016), though we could not find any significant effect on risk sharing strategies. Although they didno't consider the analogous risk management strategies. Thirdly, subjective risk perception of value chain challenges, institutional challenges and societal challenges have significant effects on risk sharing strategies. This study infers that longer value chains and stronger institutional values in food-retailers lead to greater uptake of risk sharing strategies of food-retailers take more risk sharing strategis and have positive effects on selecting risk sharing activities. However, societal challenges negatively effect risk sharing strategies. The food-retailers may prefer to take more on-business risk sharing strategies during greater social challenges. It precisely suggests that a food-retailer with a better understanding of value chain challenges and institutional challenges is more likely to take insurance, commodity future exchanges or off-business investments. Finally, the relative degree of risk attitude at marketing and promotion, attitudes on innovation and business-in-general have significant effects on risk sharing strategies. The risk-loving attitude in marketing and promotion and business in-general have significant negative effects on the selection of risk sharing instruments. For example, under, 'relative degree of risk loving attitude at marketing and promotion', the -0.197 for risk sharing strategies suggests that for one unit increase in 'relative degree of risk loving attitude at marketing and promotion' score, the multiple regression coefficient for 'risk sharing strategies' will decrease by that amount. In other words, if the relative degree of risk loving attitude at marketing and promotion increases by one unit, the chance of using risk sharing strategies are higher. The same explantion is true for innovation and business-in-general. This result is also confirmed by the findings of Meuwissen, Huirne \& Hardaker (2001), Winsen et al., (2016), Flaten et al., (2005), and Saqib et al., (2016). They also find a significant influence of risk perception and business risk behaviour.

\section{General Discussion}

This study holistically describes off-business risk sharing strategies because it designates risk sharing strategies not only as a risk management instrument, but also describes the features, types and relationships of each off-business risk sharing strategies. The aim of the discussion is three-fold: first, aim to find out the factors that matter in selecting risk sharing instruments forfood-retailers. second, compare the findings of this study with the findings of previous research in risk sharing, and risk management, and third, the novelty, explore the factors that matter in selecting different risk sharing instruments for food-retailers, particularly in Chittagong, Bangladesh. To accomplish these aims, this discussion is based on the results of the analysis. 109 food-retailers from almost 6000 food-retailers in Chittagong represent only $1.81 \%$ of the total. To attain external validity and to be statistically conclusive, the number respondents should be at least 362 food-retailers with a for $95 \%$ confidence interval and 5\% margin of error. The data in this study is therefore not representative for the entire population. However, this study collects data from primary sources and all areas in the Chittagong metropolitan area and its surroundings. The outcomes of this analysis may be different whenever a larger sample and other variables are considered for analysis. This study does not suggest any optimal risk sharing strategies for the food industry or any food-retailer specially. The selection of any risk sharing instrument depends on managerial decisions and situational circumstances. The selection of risk sharing instruments may be time oriented, yield based, et cetera. Finally, most of the findings of this study justify the findings of previous studies (regarding other industries) with a few novelties. However, most of the previous studies focus on specific risk sharing strategies or on-business risk sharing instruments of the agricultural industry. The factors that affect the selection of risk sharing strategies in food-retailing in Chittagong, Bangladesh, is the main novelty of this study.

\section{Conclusion}

Risk sharing strategies provide the opportunities for food-retailers to mitigate risk. It is also used to improve the commitment of stakeholders of consumer goods of food-retailing which through the distribution risk amongst multiple parties. Much research has studied risk management strategies from various perspectives and has enriched risk 
management literature for stakeholders and policy makers. Based on previous studies and practical relevance we studied off-business risk sharing strategies. To do this a set of predictors are used and necessary hypotheses are set for analysis in order to accomplish the objectives. Just as in the literature, ten predictors have a significant effect on risk-sharing strategies, therefore the findings of this study is in alignment with previous research. We did not cover the factors relating to technology, nor make economic claims of risk sharing strategies. The result would be different and more comprehensive if these factors were be considered. Finally, further research is needed to produce more insight into the effect of other factors through another analysis. For example, the effects of adaptability and resilience of food-retailers in the selection of risk sharing strategies might be a subject matters for future research.

\section{References}

Belsley, K., Kuh, E., \& Welsch. (1980). Regression Diagnostics. New York, NY: Wiley Belsley Regression Diagnostics. https://doi.org/10.1002/0471725153

Benjamin, C., \& Kimhi, A. (2006). Farm work, off-farm work, and hired farm labour: estimating a discrete-choice model of French farm couples' labour decisions. European Review of Agricultural Economics, 33(2), 149-171.

Campbell, S. (2005). Determining overall risk. Journal of Risk Research, 8, 569-581.

Chavas, J. P. (2004). Risk analysis in theory and practice. Elsevier.

Dohmen, T., Falk, A., Huffman, D., Sunde, U., Schupp, J., \& Wagner, G. G. (2011). Individual risk attitudes: Measurement, determinants, and behavioural consequences. Journal of the European Economic Association, 9(3), 522-550. https://doi.org/10.1111/j.1542-4774.2011.01015.x

Emerick, K., de Janvry, A., Sadoulet, E., \& Dar, M. (2016). Technological Innovations, Downside Risk, and the Modernization of Agriculture. American Economic Review, 106(6), 1537-1561.

Feder, G., \& Umali, D. L. (1993). The adoption of agricultural innovations: a review. Technological forecasting and social change, 43(3-4), 215-239. https://doi.org/10.1016/0040-1625(93)90053-A

Finocchio, R., \& Esposti, R. (2008). Determinants of farm diversification and interaction with the CAP. An application to FADN of Marche region (Italy) (No. 725-2016-49678).

Flaten, O., Lien, G., Koesling, M., Valle, P., \& Ebbesvik, M. (2005). Comparing risk perceptions and risk management in organic and conventional dairy farming: empirical results from Norway. Livestock Production Science, 95(1-2), 11-25. https://doi.org/10.1016/j.livprodsci.2004.10.014

Hansson, H., \& Lagerkvist, C. J. (2012). Measuring farmers' preferences for risk: a domain-specific risk preference scale. Journal of Risk Research, 15(7), 737-753. https://doi.org/10.1080/13669877.2012.657217

Harwood, J. L., Heifner, R. G., Coble, K. H., Perry, J. E., \& Somwaru, A. (1999). Managing Risk in Farming: Concepts, Research, and Analysis. Agricultural Economics Report No. 774, USDA/Economic Research Service, Commodity Economics Division, Washington, DC.

Holly Wang, H., Zhang, Y., \& Wu, L. (2011). Is contract farming a risk management instrument for Chinese farmers?. China Agricultural Economic Review, 3(4), 489-505. https://doi.org/10.1108/17561371111192347

Holzmann, R., \& Jørgensen, S. (2001). Social risk management: A new conceptual framework for social protection, and beyond. International Tax and Public Finance, 8(4), 529-556. https://doi.org/10.1023/A:1011247814590

Larson, D. F., Savastano, S., Murray, S., \& Palacios-López, A. (2015). Are women less productive farmers? How markets and risk affect fertilizer use, productivity, and measured gender effects in Uganda. The World Bank.

Lucas, M. P., \& Pabuayon, I. M. (2011). Risk perceptions, attitudes, and influential factors of rain fed lowland rice farmers in Ilocos Norte, Philippines. Asian Journal of Agriculture and Development, 8, 61-77.

Mahul, O., \& Stutley, C. J. (2010). Government support to agricultural insurance: Challenges and options for developing countries. Washington DC: World Bank. https://doi.org/10.1596/978-0-8213-8217-2

Marcle, F. (1999). Risk-sharing and quasi-credit. Journal of International Trade \& Economic Development, 8(3), 257-278. https://doi.org/10.1080/09638199900000016

Menapace, L., Gregory, C., \& Roberta, R. (2013). Risk Aversion, Subjective Beliefs, and Farmer Risk Management Strategies. American Journal of Agricultural Economics, 95(2), 384-389.

Meraner, M., \& Finger, R. (2019). Risk perceptions, preferences and management strategies: evidence from a case study using German livestock farmers. Journal of Risk Research, 22(1), 110-135.

Meraner, M., Heijman, W., Kuhlman, T., \& Finger, R. (2015). Determinants of farm diversification in the Netherlands. Land Use Policy, 42, 767-780. https://doi.org/10.1016/j.landusepol.2014.10.013 
Meuwissen, M., Hardaker, J., Huirne, R., \& Dijkhuizen, A. (2001). Sharing risks in agriculture; principles and empirical results. NJAS - Wageningen Journal of Life Sciences, 49(4), 343-356.

Meuwissen, M., Huirne, R., \& Hardaker, J. (2001). Risk and risk management: an empirical analysis of Dutch livestock farmers. Livestock Production Science, 69(1), 43-53. https://doi.org/10.1016/S0301-6226(00)00247-5

Mishra, A. K., El-Osta, H. S., \& Sandretto, C. L. (2004). Factors affecting farm enterprise diversification. Agricultural Finance Review, 64(2), 151-166. https://doi.org/10.1108/00214660480001160

Mishra, A., \& El-Osta, H. (2002). Managing risk in agriculture through hedging and crop insurance: what does a national survey reveal?. Agricultural Finance Review, 62(2), 135-148.

Muller, B., Johnson, L., \& Kreuer, D. (2017). Maladaptive outcomes of climate insurance in agriculture. Global Environmental Change, 46, 23-33. https://doi.org/10.1016/j.gloenvcha.2017.06.010

Munshi, K., \& Rosenzweig, M. (2006). Why is mobility in India so low? Social insurance, inequality, and growth. Discussion paper, Yale University.

Murgai, R., Winters, P., Sadoulet, E., \& de Janvry, A. (2002). Localized and incomplete mutual insurance. Journal of Development Economics, 67, 245-274. https://doi.org/10.1016/S0304-3878(01)00189-4

Nadezda, J., Dusan, M., \& Stefania, M. (2017). Risk factors in the agriculture sector. Agricultural Economics (Zemědělská Ekonomika), 63(6), 247-258. https://doi.org/10.17221/212/2016-AGRICECON

Pennings, J. M., \& Garcia, P. (2001). Measuring producers' risk preferences: A global risk-attitude construct. American Journal of Agricultural Economics, 83(4), 993-1009. https://doi.org/10.1111/0002-9092.00225

Pennings, J. M., \& Smidts, A. (2000). Assessing the construct validity of risk attitude. Management science, 46(10), 1337-1348. https://doi.org/10.1287/mnsc.46.10.1337.12275

Pocuca, M., Petrovic, Z., \& Mrksic, D. (2018). Insurance in agriculture. Economics of Agriculture, 60(1), 163-177.

Retrieved from http://www.thestrategywatch.com/restaurant-industry-bangladesh/

Retrieved from https://ec.europa.eu/eurostat/statistics-explained/index.php/Glossary:Livestock_unit_(LSU)

Retrieved from https://www.cbs.nl/en-gb

Saqib, S., Ahmad, M. M., Panezai, S., \& Ali, U. (2016). Factors influencing farmers' adoption of agricultural credit as a risk management strategy: The case of Pakistan. International Journal of Disaster Risk Reduction, 17, 67-76. https://doi.org/10.1016/j.ijdrr.2016.03.008

Shiferaw, B., Okello, J., \& Reddy, R. (2007). Adoption and adaptation of natural resource management innovations in smallholder agriculture: reflections on key lessons and best practices. Environment, Development and Sustainability, 11(3), 601-619. https://doi.org/10.1007/s10668-007-9132-1

Starks, H., \& Brown, T. S. (2007). Choose your method: A comparison of phenomenology, discourse analysis and grounded theory. Qualitative Health Research, 17(10), 1372-1380. https://doi.org/10.1177/1049732307307031

Ullah, R., Shivakoti, G. P., \& Ali, G. (2015). Factors effecting farmers' risk attitude and risk perceptions: the case of Khyber Pakhtunkhwa, Pakistan. International Journal of Disaster Risk Reduction, 13, 151-157.

van Winsen, F., de Mey, Y., Lauwers, L., Van Passel, S., Vancauteren, M., \& Wauters, E. (2016). Determinants of risk behaviour: effects of perceived risks and risk attitude on farmer's adoption of risk management strategies. Journal of Risk Research, 19(1), 56-78. https://doi.org/10.1080/13669877.2014.940597

Velandia, M., Rejesus, R., Knight, T., \& Sherrick, B. (2009). Factors Affecting Farmers' Utilization of Agricultural Risk Management Tools: The Case of Crop Insurance, Forward Contracting, and Spreading Sales. Journal of Agricultural and Applied Economics, 41(1), 107-123. https://doi.org/10.1017/S1074070800002583

Wauters, E., van Winsen, F., de Mey, Y., \& Lauwers, L. (2014). Risk perception, attitudes towards risk and risk management: evidence and implications. Agricultural Economics (Zemédělská Ekonomika), 60(9), 389-405. https://doi.org/10.17221/176/2013-AGRICECON

\section{Copyrights}

Copyright for this article is retained by the author(s), with first publication rights granted to the journal.

This is an open-access article distributed under the terms and conditions of the Creative Commons Attribution license (http://creativecommons.org/licenses/by/4.0/). 